\title{
Longstanding Unrecognized Wooden Foreign Bodies in Oro-facial Region, Report of three Cases
}

\author{
Sanadi Sajid Ahmed ${ }^{1, *}$, Sabina Abid ${ }^{2}$, Yasser Al-Thobaiti ${ }^{3}$, S. D. Baliga ${ }^{4}$, Mohammed Fayyaz ${ }^{5}$ \\ ${ }^{1}$ Registar Department of Oral \& Maxillofacial Surgery, Al-Noor Specialist Hospital, Makkah, Kingdom of Saudi Arabia \\ ${ }^{2}$ Departement of Oral and Maxillofacial Sciences, Al-Farabi College of Dentistry, Kingdom of Saudi Arabia \\ ${ }^{3}$ Department of Oral \& Maxillofacial Surgery, Faculty of Dentistry Taif University, Kingdom of Saudi Arabia \\ ${ }^{4}$ Department of Oral \& Maxillofacial Surgery KLES’s VK Institute of Dental Sciences and Hospital Belgaum, India \\ ${ }^{5}$ Badar Al-Samaa Polyclinic, Jeddah, Kingdom of Saudi Arabia \\ *Corresponding author: drsanadi@yahoo.com, sajidsanadi5@gmail.com
}

Received June 12, 2015; Revised June 18, 2015; Accepted July 03, 2015

\begin{abstract}
Retention of foreign bodies in maxillofacial region following trauma are not uncommon. Various retained foreign bodies reported; are tooth fragments, root canal filling material, burs, sewing needles, broken tips of probes and elevators, wooden tooth picks, piece of glass, blades of grass, a tooth brush bristle, fish bone, hair, piece of straw or grass, portion of fingernail, spike of wheat, thorn and chicken pinfeather, surgical gauze. Some times these foreign bodies get infected and spontaneously come out through draining sinus. But very rarely it is possible that some might remain in the soft tissue and go unnoticed, causing persistent pus discharge, trismus, granuloma and osteomyelitis. This article describes three cases of retained wooden foreign bodies in cheek, parotid gland and tongue with their diagnosis and management.
\end{abstract}

Keywords: wooden foreign bodies, draining sinuses, parotid fistula

Cite This Article: Sanadi Sajid Ahmed, Sabina Abid, Yasser Al-Thobaiti, S. D. Baliga, and Mohammed Fayyaz, "Longstanding Unrecognized Wooden Foreign Bodies in Oro-facial Region, Report of three Cases." American Journal of Public Health Research, vol. 3, no. 4 (2015): 157-161. doi: 10.12691/ajphr-3-4-5.

\section{Introduction}

Soft tissue injuries of head and neck are very common following any trauma, as face is the most exposed part of the human body. During course of trauma it is possible that various radio opaque foreign bodies like tooth fragments [20], root canal filling material, burs, sewing needles [3], broken tips of probes and elevators. [11] Various radio lucent foreign bodies like wooden tooth picks $[8,10]$, piece of glass, blades of grass [5], tooth brush head [21] a tooth brush bristle, fish bone, hair, piece of straw or grass, portion of fingernail, spike of wheat, thorn and chicken pinfeather [3,8,10], might get entangled within the soft tissue, either in the lacerated wounds or in the soft tissue pockets. Generally these foreign bodies are removed prior to repair of soft tissue. But very rarely it is possible that some might remain in the soft tissue and go unnoticed.

These case reports describe similar cases where wooden foreign bodies were retained in the right cheek of a ten year old boy, left parotid gland of five years old boy and tongue of a forty year old man following fall from tree. The most common signs and symptoms of retention of any foreign body in maxillofacial region; are either swelling with pus discharging sinuses, trismus, sloughing of soft tissue or granuloma [18]. Exploration with debridement of wound gives the best results in these cases.

\section{Case 1}

A ten year old boy was referred to Maxillofacial Surgery with the complaint of persistent swelling in the right cheek region with discharge of pus. The history revealed that one and half month ago, the child had slipped and fallen from the mango tree, following which there was a penetrating wound in the right cheek which bleed profusely. He was immediately taken to near by Hospital where preliminary treatment was given after ruling out fracture of any facial bones or damage to other facial structures.

Initially the healing was uneventful but one month later parent's noticed a swelling on right cheek which was gradually increasing in size with pain and partial restriction in mouth opening. Patient reported back to the hospital where he was put on course of antibiotics, with no further improvement in the condition. Subsequently patient was referred to our institution, with a diffused swelling on the right side of the cheek and discharging sinus within the swelling. Routine radiographs did not reveal any pathology or presence of foreign body within the wound. It was decided to surgically explore the wound under sedation with local anesthesia. During the surgical exploration, three pieces of wood deep inside the soft tissue pocket were removed (Figure 1). 


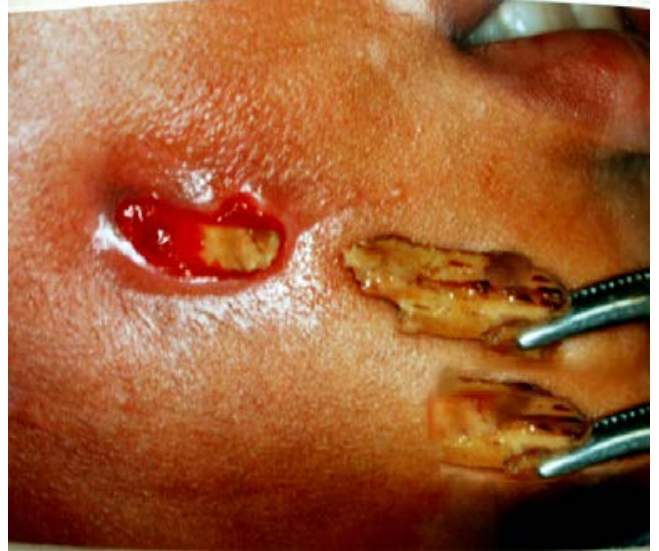

Figure 1. Three pieces of wood were removed from soft tissue pocket

The wood pieces put together was measuring about 28 $\mathrm{mm}$ in length. After removing foreign body, the wound was explored for any further foreign bodies and proper debridement was performed to remove unhealthy granulation tissue. Since there was a large collection of granulation tissue and long-standing infection, it was decided to keep wound open, to allow healing by secondary intention.

The postoperative sequel was uneventful and wound healed within period of one week. One-year follow up did not show any uneventful healing except patient had mild degree of scarring at wound site (Figure 2).

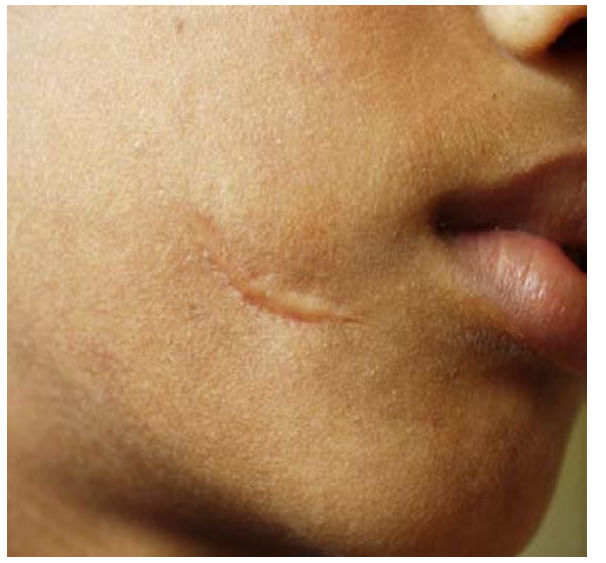

Figure 2. Uneventful healing with mild degree of scarring

\section{Case 2}

A five year-old boy was referred to our clinic with the complain of swelling on left side of cheek since 4 days. Patient's father gave history that the child has fallen down from tree while playing. Following which there was cut wound in left cheek measuring about $2 \mathrm{cms}$ and this was caused by penetrating wood. The child was taken to near by hospital where the debridement of wound and closure was done after removing wooden foreign body. Upon examination patient had discharge of pus, thinking it is an infected hematoma evacuation of hematoma was done through same cut wound and patient continued antibiotics and regular dressing for one week.

Initially the healing was uneventful. Two weeks later patient came back with parents complaining of swelling on left cheek which was gradually increasing in size with pain and pus discharge from the wound. Upon examination there was pus discharge from fistula in cheek fallowed by blood and clear fluid. (Figure 3) Intra orally clear discharge of saliva through Steson's duct was noticed.

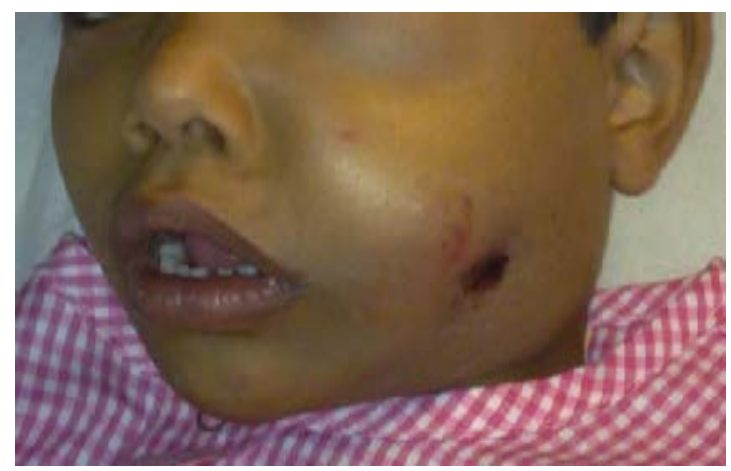

Figure 3. Swelling and fistula in cheek

The wound debridement was done under local anesthesia and was put on course of antibiotics, patient came back to hospital after one month with no further improvement in the condition. Subsequently patient was subjected to ultrasound of left parotid gland (Figure 4).

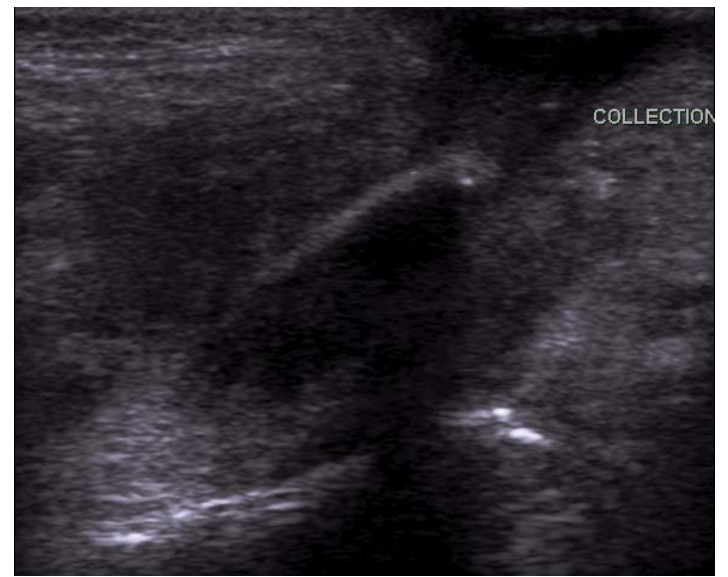

Figure 4. Ultrasound showing hyperechoic shadow measuring $14 \mathrm{~mm}$ inside the collection suggestive of foreign body

The ultrasound report revealed there was collection seen in the left parotid region measuring about $27 \mathrm{~mm} \mathrm{X} 8$ mm with sinus tract connected with skin a hyperechoic shadow measuring $14 \mathrm{~mm}$ was seen inside the collection suggestive of foreign body.

It was decided to surgically explore the wound under general anesthesia. During the surgical exploration, a piece of wood deep inside the soft tissue pocket was removed measuring about $14 \mathrm{~mm}$ (Figure 5).

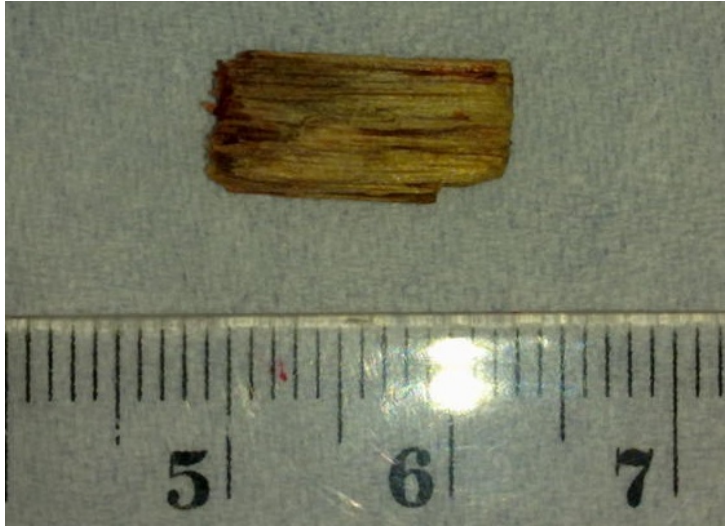

Figure 5. Wooden foreign body removed from parotid gland 
Since there was a large collection of granulation tissue and long-standing infection, and discharge of saliva it was decided to keep wound open, to allow healing by secondary intention. Post-operative healing was uneventful.

\section{Case 3}

A forty year male patient reported to Maxillofacial Surgery complaining of pus discharge from tongue since two years. Past history revealed patient had trauma, while climbing a coconut tree due to fall of a branch of the same tree. After which he had facial lacerations for which he took treatment at local hospital. Two months later patient had noticed pus discharge from the left lateral side of tongue.

He was operated twice elsewhere without succession of primary complain. Examination of tongue with application of dye, revealed three sinuses on left lateral side on dorsum of tongue (Figure 6).

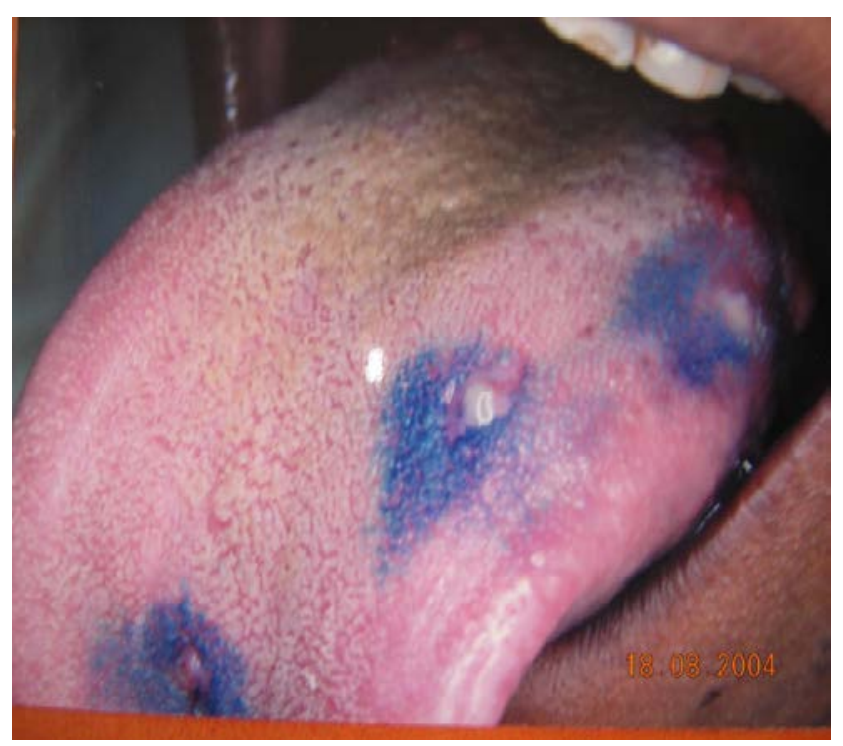

Figure 6. Three sinuses are seen on lateral side of tongue after application of dye

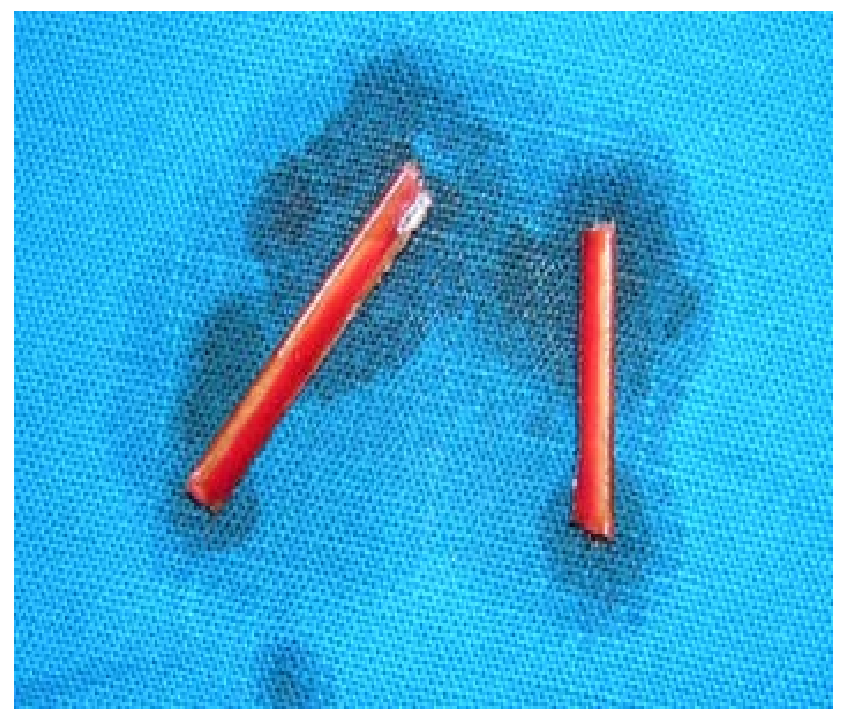

Figure 7. Wooden foreign bodies ( bark of coconut tree) removed from tongue
Routine radiographs and CT scans did not reveal any foreign body. Ultra sound of tongue revealed some unusual thin mass deep in tongue muscles. Exploration and debridement of sinus was planned under general anesthesia. During surgery on deep exploration two pieces of bark of coconut tree from deep muscle of tongue measuring about $25 \mathrm{~mm}$ in length were removed (Figure 7).

The sinus lining was curetted, debridement of wound was done, primary closure was achieved with uneventful healing

\section{Discussion}

Foreign bodies present a diagnostic challenge to even the experienced surgeon. In one review of 200 surgical cases involving retained foreign bodies, one-third of the cases had been initially missed. Wooden foreign bodies in particular pose a challenge to the physician, only $15 \%$ of wooden foreign bodies were well visualized on plain radiographs [16].

Small lacerations and penetrating wounds of the face are often associated with retained foreign bodies in the soft tissue that may not be detected during the initial examination $[5,10]$ or history suggestive of foreign body may be absent $[7,17]$. In such cases 'biological' material, wood possesses a great potential for late complication such as cervical abscess, draining fistula of cheek, parotid fistula, osteomylitis, bone destruction, granuloma, trismus [14] paresthesia of adjoining nerves [12] major vascular thrombosis, cavernous sinus thrombosis, brain abscess [15] and death have been reported [5,6, 8,10].

The factors responsible for retention of foreign bodies in soft tissue following injuries are; the face and tongue has an ability to accommodate large foreign bodies, without disturbing function and contour. Diagnosis and localization may be confirmed with plain radiographs and tomograms, if the foreign body is metallic, but in case of deeply positioned radiolucent objects like glass [5], wood and plastic etc may remain undetected. Immediately after trauma CT-scan is usually performed in cases where foreign bodies are suspected. But it is well known that a wooden foreign body can initially present as hypodenced on CT-scan and consequently be diagnosed as air $[15,16]$ or fat [19]. However, early CT has some limitations in evaluating suspected retained foreign bodies. Vascular injuries, small foreign bodies [5], and objects with densities similar to surrounding tissues present difficulties in CT evaluation [6]. In movable structures like tongue sonography is much useful.

The facial soft tissue tends to close around the retained foreign body in small penetrating wounds. The rate of retention is higher in children because it may not be possible to obtain an adequate history of injury and profound clinical examination. These foreign bodies can occasionally harm salivary glands producing facial nerve palsy [12] cutaneous fistula if they are in parotid gland.

Most objects are superficially embraded and hence removed by the patients or parents in case of child or by the general practitioner. [7] If initially; radiologically missed or misdiagnosed, the appropriate trauma setting a penetrating wooden body must always be considered. Superficially retained wooden foreign bodies can be most reliably detected with ultrasonography if they are not 
obscured by overlying bone or gas $[15,16]$ Dry wood is porous while fresh wood has capillaries, which cause differences in their densities. After forty eight hours the wooden foreign body absorbs water and lymphatic from the surrounding tissues therefore, its density increases, and can be detected in CT $[1,9,13,15]$ Calcifications may occur in the presence of a foreign object over along period [9]. Foreign bodies often incite a chronic inflammatory reaction with the deposition of mineral salts, similar to other types of calculi formation such as sialolithiasis, rhinolith and tonsillolith [4]. When wood induces calcification, it can be detected by conventional radiographic exams. On the other hand, the toothpick fragment could only be observed by macroscopic or microscopical analyses. [2] If CT scans do not reveal a suspected wooden fragment, MRI should be carried out [15]. Although MR imaging may demonstrate wooden foreign bodies in some anatomical sites, the absence of such identification does not exclude the possibility of a retained foreign object [14].

Embedded foreign bodies induce a reparative granuloma formation [18], which surrounds them, making their detection by the naked eye difficult during surgery. This fact explains the failure to detect the wooden foreign body in spite of several surgical interventions. This also emphasises the need for performing an ultrasound as a preferred imaging modality for detection of wooden foreign bodies in soft tissues [1].

Summery: Table 1 Showing various long standing foreign bodies (FB) in maxillofacial region.

Table 1. Studies showing various long standing foreign bodies (FB) in maxillofacial region

\begin{tabular}{|c|c|c|c|c|c|c|}
\hline Sl. No & Authors & Chief complain & Etiology & Lag period & Diagnostic methods & Type of FB \\
\hline 1 & $\begin{array}{l}\text { A Auluck et.al } \\
{[1]}\end{array}$ & $\begin{array}{l}\text { Sinus of the right } \\
\text { cheek }\end{array}$ & Fall from a bicycle & 81 days & Ultrasound & Wooden splinter \\
\hline 2 & $\begin{array}{l}\text { Akgüner M et.al } \\
\text { [22] }\end{array}$ & $\begin{array}{l}\text { Severe infection of } \\
\text { orbit }\end{array}$ & Self-inflicted injury & 6 months & $\begin{array}{l}\text { Magnetic resonance } \\
\text { imaging }\end{array}$ & Wooden , piece 55 X 6 mm \\
\hline 3 & $\begin{array}{l}\text { Soubhia A. et.al } \\
\text { [2] }\end{array}$ & $\begin{array}{l}\text { Swelling in the } \\
\text { incisive papilla }\end{array}$ & $\begin{array}{l}\text { Traumatic laceration of } \\
\text { the incisive papilla with } \\
\text { a toothpick }\end{array}$ & 15 years & $\begin{array}{l}\text { Calcified mass examined } \\
\text { under Electron } \\
\text { Microscope after removal }\end{array}$ & Piece of wood $1 \mathrm{~cm}$ \\
\hline 4 & $\begin{array}{l}\text { Basile N Landis } \\
\text { et.al [2] }\end{array}$ & $\begin{array}{l}\text { Neck mass without } \\
\text { other signs and } \\
\text { symptoms }\end{array}$ & Unknown & 2 months & $\begin{array}{l}\text { Surgical exploration under } \\
\text { GA }\end{array}$ & Blade of grass \\
\hline 5 & $\begin{array}{l}\text { Robinson P D. } \\
\text { et.al [14] }\end{array}$ & $\begin{array}{l}\text { Persistent and } \\
\text { distressing symptoms } \\
\text { on face }\end{array}$ & Unknown & 9 years & Radiological identification & Wooden foreign body \\
\hline 6 & $\begin{array}{l}\text { Siegfried et.al } \\
\text { [15] }\end{array}$ & $\begin{array}{l}\text { Pain and swelling in } \\
\text { retromaxillary space }\end{array}$ & Unknown & 2 years & Surgical exploration & Wooden foreign body \\
\hline 7 & $\begin{array}{l}\text { Woolley et.al } \\
{[16]}\end{array}$ & $\begin{array}{l}\text { diffusely enhanced } \\
\text { left parotid gland }\end{array}$ & Unknown & 3 years & CT scan & $1.7 \mathrm{~cm}$ metallic wire \\
\hline 8 & $\begin{array}{l}\text { Anne Vikram } \\
\text { et.al [17] }\end{array}$ & $\begin{array}{l}\text { extra oral swelling } \\
\text { with pus discharge } \\
\text { and trismus }\end{array}$ & Road traffic accident & 2 years. & CT scan & A wooden piece $3 \times 1 \mathrm{~cm}$ \\
\hline 9 & $\begin{array}{l}\text { Sripathi Rao BH } \\
\text { et.al [18] }\end{array}$ & $\begin{array}{l}\text { Pain and swelling in } \\
\text { upper right lip and } \\
\text { cheek }\end{array}$ & road traffic accident & 6 months & Surgical exploration & $\begin{array}{l}\text { A wooden piece } 3.2 \times 0.5 \\
\mathrm{~cm}\end{array}$ \\
\hline 10 & $\begin{array}{l}\text { Rudgi BM et.al } \\
\text { [23] }\end{array}$ & $\begin{array}{l}\text { Pain and swelling } \\
\text { iright infraorbital area }\end{array}$ & fall from a motor icycle & 5 years & Surgical exploration & Thorn $3 X 0.2 \mathrm{cms}$ \\
\hline 11 & $\begin{array}{l}\text { Manoel Leal } \\
\text { Filho et.al [24] }\end{array}$ & $\begin{array}{l}\text { Ptosis and limitation } \\
\text { in right eye } \\
\text { movement }\end{array}$ & Hit by branch of tree & 2 months & CT scan & $\begin{array}{l}\text { A wooden fragment } 2 \times 0.3 \\
\mathrm{cms}\end{array}$ \\
\hline 12 & $\begin{array}{l}\text { SB Aregbesola } \\
\text { et.al [21] }\end{array}$ & $\begin{array}{l}\text { painful right cheek } \\
\text { swelling with trismus }\end{array}$ & $\begin{array}{l}\text { Fell off his motorcycle } \\
\text { into a ditch containing } \\
\text { wooden sticks }\end{array}$ & 4-week & Exploration under LA & $\begin{array}{l}\text { wooden stick, measuring } \\
2.5 \mathrm{~cm} \text { by } 6.5 \mathrm{~cm}\end{array}$ \\
\hline 13 & $\begin{array}{l}\text { Mohanavali } \\
\text { David et.al [20] }\end{array}$ & $\begin{array}{l}\text { discharge from right } \\
\text { angle }\end{array}$ & $\begin{array}{l}\text { Accident } 6 \text { months } \\
\text { earlier }\end{array}$ & 4 months & Exploration under GA & $\begin{array}{l}\text { A wooden fragment } 3 \mathrm{X} \\
\text { 31cms }\end{array}$ \\
\hline \multirow{3}{*}{14} & \multirow{3}{*}{$\begin{array}{l}\text { Sanadi sajid et.al } \\
\text { (present report) }\end{array}$} & $\begin{array}{l}\text { 1) Swelling and pus } \\
\text { discharge }\end{array}$ & Fallen from mango tree. & 45 days & $\begin{array}{l}\text { Exploration under } \\
\text { LA. }\end{array}$ & $\begin{array}{l}3 \text { wooden fragments of } 28 \\
\text { mm. }\end{array}$ \\
\hline & & $\begin{array}{l}\text { 2) Swelling in left } \\
\text { cheek }\end{array}$ & Fallen from tree. & One month & Ultrasound. & A wooden fragment $14 \mathrm{~mm}$ \\
\hline & & $\begin{array}{l}\text { 3)Pus discharge from } \\
\text { tongue }\end{array}$ & $\begin{array}{l}\text { Fall of branch of } \\
\text { coconut tree }\end{array}$ & Two years & Exploration under GA. & $\begin{array}{l}2 \text { barks of coconut tree } 25 \\
\text { mm. }\end{array}$ \\
\hline
\end{tabular}

GA: General Anaesthesia,

LA: Local Anaesthesia.

In most of the case reports including our, attempt is made to remove the visible FB by patients, parents or primary treating physicians. The wooden FB might brake during removal or at the time of trauma itself, hence through clinical examination including deep bimanual palpation of soft tissue should be done to search FB. One should also explore the existing wound with curved artery forceps or use ultrasound for survey. The foreign body should be expected unless proven otherwise.

This article emphasizes the necessity for careful assessment of penetrating facial wounds, no matter how small they may appear. In all penetrating wounds suspected FB, are highly contaminated with organic matters and micro organisms in spore form, patients prophylactic tetanus should be considered. Long-term follow-up is also necessary, even if patient remains asymptomatic to prevent further complication caused by retained FB.

1)- commenting on the prophylactic tetanus status:

In all penetrating wounds suspected FB, are highly contaminated with organic matters and micro organisms in spore form, patients prophylactic tetanus should be considered.

2)- commenting that physical examination should include deep palpation of soft tissue in order to feel such large 
pieces in the face ... and that might be a message to the ER team whom missed that ...

In most of the case reports including our, attempt is made to remove the visible $\mathrm{FB}$ by patients, parents or primary treating physicians. The wooden FB might brake during removal or at the time of trauma itself, hence through clinical examination including deep bimanual palpation of soft tissue should be done to search FB. One should also explore the existing wound with curved artery forceps or use ultrasound for survey. The foreign body should be expected unless proven otherwise. This article emphasizes the necessity for careful assessment of penetrating facial wounds, no matter how small they may appear.

\section{Statement of Competing Interests}

The authors have no competing interests.

\section{References}

[1] A Auluck, A. G. Behanan, K. M. Pai and C. Shetty; Recurrent sinus of the cheek due to a retained foreign body: Report of an unusual case, British Dental Journal 2005; 198: 337-339.

[2] A.M.P.Soubhia, A.C.P.Ribeiro, L.D.Martins, A.R.S.Silva and M.A.Lopes; Unusual wooden foreign body in the palate, British Dental Journal 2007; 203:573-574.

[3] Anders H. Westermark; Spontaneous Removal of Foreign Bodies in the Maxillary Sinus: Report of a case, J. Oral \& Maxillofacial Surgery 1989: 47: 75-77.

[4] Barros C A, Martins R R,Silva J B et al; Rhinolith, A radiographic finding in a dental clinic, Oral Surg Oral Med Oral Pathol Oral Radiol Endod 2005; 100:486-490.

[5] Basile N Landis and Roland Giger; An unusual foreign body migrating through time and tissues Head \& Face Medicine 2006 $2: 30$.

[6] Daniel D. Lydiatt, Ronald R Hollins, David J. Moyer, Leon F. Davis; Problems in Evaluation of Penetrating Foreign Bodies with Computed Tomography Scans: Report of Cases. Oral \& Maxillofacial Surgery 1987: 4: 965-968.

[7] E. J. Da Silva, Y. Deng, C. G. Tumushime- Buturo; An Unusual Foreign Body in Tongue, British Journal of Oral \& Maxillofacial Surgery 2000:38: 2411-242.
[8] Guillermo Raspall, Javier Gonzalez; An Unusual Case of Intraparotid Foreign Body, J. Oral \& Maxillofacial Surgery 1990: 48:628-630.

[9] Hideki Imokawa, Takasi Tazawa, Natuki Sugiura, Daisuke Oyake, Kiyomi Yosino; Penetrating neck injuries involving wooden foreign bodies: the role of MRI and the misinterpretation of CT images Auris, Nasus, Larynx 2003:30:145-147.

[10] Ioannis Dimitrakopoulos, Nicolaos Lazaridis, Dimiyri Karakasis; An Unusual Retained Foreign Body in The Orbit, J. Oral \& Maxillofacial Surgery 1991:49:420-421.

[11] J. Moore, K. Fanibunda, M. J. Gross; The Use of Metal Detector for a Metallic Foreign Body in The Floor of Mouth. British Journal of Oral \& Maxillofacial Surgery. 1993: 31: 191-192.

[12] Kapila B. K., Jeevan. Lata; Unusual foreign bodies: three case reports, J. Oral Maxillofac. Surg. 1995; 24: 208-209.

[13] Krimmel M, Cornelius CP, Stojadinovic S, Hoffmann J, Reinert S; Wooden foreign bodies in facial injury: a radiological pitfall, Int J Oral Maxillofac Surg. 2001 Oct; 30(5):445-7.

[14] P. D. Robinson, V. Rajayogeswaran, R; Unlikely foreign bodies in unusual facial sites, British J. Oral Maxillofac. Surg. 1997: 35: 3639.

[15] Siegfried Jinicke, Wilfried Wagner; Retained pieces of wood in the retromaxillary space: a case report, J Of cranio Maxillofac Surg 1995: 23:312-316.

[16] Woolley, Audie L. Wimberly, Lee T.Royal, Stuart A; Retained wooden foreign body in a child's parotid gland. Ear, Nose \& Throat Journal; Feb98, Vol. 77 Issue 2, 140, 144.

[17] Anne Vikram; Wooden foreign body in the zygomatic region for 2 years. J. Maxillofac. Oral Surg. Mar 2012; 11(1): 96-100.

[18] Rao Sripathi BH, Joyce S, Mapilly, Firdoose CS; J. Maxillofac. Oral Surg. Sept 2014; 13(3): 351-354.

[19] Javad Rashid R; Visibility of different foreign bodies in the maxillofacial region using plain radiography, CT, MRI and Ultrasonography: an in vitro study. Dentomaxillofac Radiol: 2014 Nov 26.

[20] Mohanavalli David J, Gnanam; A rare case of foreign body in orofacial refions. Indian J Dent Res. 2011 Dec 22: 713-15.

[21] Aqegbesola SB, Uqboko; Unusual foreign bodies in the orofacial soft tissue spaces: A report of three cases. Niger J Clin Pract, 2013 Vol(16) 381-385.

[22] Akgüner M, Atabey A, Top H; A case of self-inflicted intraorbital injury: wooden foreign body introduced into the ethmoidal sinus. Ann Plast Surg. 1998 Oct; 41(4):422-4.

[23] Rudagi BM, Halli R, Kini Y, Kharkhar V, Saluja H Foreign bodies in facial trauma-report of 3 cases, J Maxillofac Oral Surg. 2013 Jun; 12(2):210-3.

[24] Manoel Baldoino Leal Filho, Bruno Ribeiro de Almeida, Aline de Almeida Xavier Aguiar, Marcelo Adriano C. S. Vieira, Ricardo Keyson P. de Morais, Karoline da Silva Dantas, Corpo estranho no cone orbitario Arq Neuropsiquiatr 2003; 61(2-B):490-493. 